\title{
RE-INTERPRETASI DAN RE-ORIENTASI PENDIDIKAN INKLUSIF
}

\author{
Nenden Ineu Herawati ${ }^{1}$ \\ Universitas Pendidikan Indonesia Kampus Cibiru
}

\begin{abstract}
The understanding of inclusive education is still inaccurate, so the interpretation and orientation towards that implementation are not appropriate as it should be. Nowadays, be found in the field that term of inclusive education is only limited to children with special needs learned together with general children in regular schools. Whereas, the term of inclusive education refer to provide the possible opportunity or access widely for all children in order to obtain the quality of education and in accordance with the needs without discrimination. Therefore, schools that enroll in inclusive education are required to adjust in terms of curriculum, facilities, the infrastructure of education, and learning systems as well that adjusted with the needs of children with special needs. In the other hand, children with special needs are those with temporary or permanent special needs that require more intense educational services. If children are required to receive an education service that is appropriate to their needs and existence through an inclusive education program, it will provide the possible opportunity widely for all children with special needs to get a proper education according to their needs. Moreover, it can create an education system that respects to diversity, non-discrimination and friendly in learning. Thus, it can implement the mandate of the Constitution of 1945, article 31, paragraph 1, Law of 2003 No. 20 regarding National Education System on article 5, paragraph 1, and Law of 2002 No 23 regarding The Right and Protection of Children in article 51.
\end{abstract}

Keyword: Children with Special Needs, Inclusive Education

\begin{abstract}
Abstrak: Pemahaman terhadap pendidikan Inklusif masih belum tepat, sehingga in terpretasi dan orientasi pelaksanaannya pun belum sesuai sebagaimana seharusnya yang sekarang dijumpai di lapangan bahwa yang dinamakan pendidikan inklusif adalah hanya sebatas anak kebutuhan khusus belajar bersama-sama dengan anak-anak normal di sekolah reguler.Padahal yang dinamakan pendidikan inklusif adalah memberikan kesempatan atau akses yang seluas-luasnya kepada semua anak untuk memperoleh pendidikan yang bermutu dan sesuai dengan kebutuhan tanpa diskriminasi, oleh karena itu sekolah yang menyeleggarakan pendidikan inklusif dituntut harus menyesuaikan baik dari segi kurikulum, sarana dan prasarana pendidikan maupun sistem pembelajaran yang sesuai dengan kebutuhan individu peserta didik yang berkebutuhan khusus. Sedangkan yang dimaksud dengan anak berkebutuhan khusus adalah mereka yang memiliki kebutuhan khusus sementara atau permanen yang membutuhkan pelayanan pendidikan yang lebih intens. Jika anak berkebutuhan mendapat layanan pendidikan yang sesuai dengan kebutuhan dan keberadaannya melalui program pemdidikan inklusif, maka akan memberikan kesempatan seluas-luasnya kepada semua anak berkebutuhan khusus mendapatkan pendidikan yang layak sesuai dengan kebutuhannya. Serta dapat menciptakan sistem pendidikan yang menghargai keanekaragaman, tidak diskriminasi serta ramah terhadap pembelajaran sehingga dapat mengamalkan amanat Undang-Undang-Undang 1945 pasal 31 ayat 1 juga undang-undang No 20 tahun 2003 tentang system pendidikan Nasional pasal 5 ayat 1 dan Undang-Undang no 23 tahun 2002 tentang hak dan perlindungan anak pasal 51.
\end{abstract}

Kata Kunci: Anak berkebutuhan khusus. Pendidikan Inklusif

\section{PENDAHULUAN}

Berdasarkan pengalaman dan pengamatan pemahaman terhadap pendidikan inklusif masih belum ajeg, jangankan dari masyarakat awam masyarakat intelekpun belum memahami secara betul berpandangan yang disebut dengan pendidikan inklusif itu adalah dimana anakanak berkebutuhan khusus belajar bersamasama dengan anak normal di sekolah-

IPGSD UPI Kampus Cibiru, Email: nendenineuherawati回upi.edu 
sekolah pada umumnya baik itu di sekolah negeri maupun sekolah swasta. Dengan beranggapan seperti itu maka pelaksanaan nyapun kurang tepat, seperti anak berkebutuhan khusus belajar bersama dengan anak normal atau rata-rata dalam satu kelas, tetapi anak berkebutuhan khusus duduk terpisah berdekatan dengan meja guru di pojok belajarnya secara individual didampingi oleh guru pendamping.

Pelaksanaan layanan pembelajaran seperti itu maka banyak Sekolah dan guruguru menolak kehadiran anak-anak berkebutuhan khusus untuk diterima di sekolah-sekolah umum, beranggapan fasilitas belum memadai termasuk pengadaan guru pendamping, layanan pendidikan bagi anak-anak normal akan terbengkalai karena akan lebih fokus memperhatikan pada anak-anak berkebutuhan khusus belum tentu berhasil dalam pembelajarannya. Sedangkan anakanak normal sudah pasti akan berhasil pembelajarannya, juga ada anggapan dari masyarakat dan para orang tua kekhawatiran jika anak-anak berkebutuhan khusus belajar bersama dengan anak-anak normal tentu akan bergaul ketakutan anakanak normal tertular oleh anak-anak berkebutuhan khusus.

Padahal pendidikan inklusif yang sebenarnya bukan seperti itu sebagaimana yang dinyatakan atau diinformasikan oleh Direktorat Pembinaan Sekolah Luar Biasa atau Dirjen PLB (2007) adalah sebagai berikut. Pendidikan Inklusif adalah sistim layanan pendidikan yang mensyaratkan anak berkebutuhan khusus belajar di sekolah-sekolah terdekat di kelas biasa bersama teman-teman seusianya (SapanShevin dalam O’Neil, 1994). Sekolah penyelenggara pendidikan inklusif adalah sekolah yang menampung semua murid di kelas yang sama. Sekolah ini menyediakan program pendidikan yang layak, menantang, tetapi disesuaikan dengan kemampuan dan kebutuhan setiap murid maupun bantuan dan dukungan yang dapat diberikan oleh para guru, agar anak berhasil (Stainback \& Sianback, 1990).
Berdasarkan batasan tersebut pendidikan inklusif yang dimaksudkan sebagai sistem layanan pendidikan yang mengikut sertakan anak berkebutuhan khusus belajar bersama dengan anak sebayanya di sekolah reguler yang terdekat dengan tempat tinggalnya. Semangat penyelenggaraan pendidikan inklusif adalah memberikan kesempatan atau akses yang seluas-luasnya kepada semua anak untuk memperoleh pendidikan yang bermutu dan sesuai dengan kebutuhan individu peserta didik tampa diskriminasi. Penyelenggaraan pendidikan inklusif menuntut pihak sekolah melakukan penyesuaian baik dari segi kurikulum, sarana, prasarana pendidikan maupun system pembelajaran yang disesuaikan dengan kebutuhan individu peserta didik. Untuk itu prodes identifikasi dan asesmen yang akurat perlu dilakukan oleh tenaga yang terlatih atau professional dibidangnya, untuk dapat menyusun program pendidikan yang sesuai dan objektif.

\section{TINJAUAN PUSTAKA}

Pada tahun 2000 Pemerintah Republik Indonesia mengembangkan program inklusif, program ini merupakan kelanjutan program pendidikan terpadu yang sesungguhnya pernah diluncurkan di Indonesia pada tahun 1980-an, tetapi kemudian kurang berkembang dan baru mulai tahun 2000 dimunculkan kembali dengan mengikuti kecenderungan dunia menggunakan konsep pendidikan inklusif. Pendidikan inklusif secara resmi didefinisikan sebagai system layanan pendidikan yang mengikutsertakan anak berkebuthan khusus belajar bersama dengan anak sebayanya di sekolah reguler yang terdekat dengan tempat tinggalnya. Penyelenggaraan pendidikan inklusif menuntut pihak sekolah melakukan penyesuaian baik segu kurikulum, sarana dan prasarana pendidikan maupun sistem pembelajaran yang disesuaikan dengan kebutuhan individu peserta didik (Ilahi, 2013 hlm 26). 
Demikian pula diungkapkan oleh Ilahi (2013, hlm 27) pendidikan inklusif sebagai pendidikan yang memberikan layanan terbuka bagi siapa saja yang memiliki keinginan untuk mengembangkan potensi-potensinya secara optimal. Sedangkan istilah anak berkebutuhan khusus berkembang seiring dengan munculnya pendidikan inklusif yang mewarnai perjalanan setiap anak Indonesia yang menghadapi segala pelabelan negatif yang diarahkan kepada mereka.

Istilah anak berkebutuhan khusus bukan berarti hendak menggantikan anak penyandang disabilitas atau anak luar biasa melainkan memiliki pandangan yang lebih luas dan positif bagi anak dengan keberagaman yang berbeda (Ilahi, 2013, hlm 137). Anak berkebutuhan khusus adalah mereka yang memiliki kebutuhan khusus sementara atau permanen sehingga membutuhkan pelayanan pendidikan yang lebih intens (Ilahi, 2013).

\section{PEMBAHASAN}

\section{Pada hakekatnya Tuhan} menciptakan manusia tidak sama unik satu dengan yang lainnya berbeda, dalam aspek fisik maupun psikis, juga keberbedaan tersebut ada yang tidak begitu mencolok dan ada yang sangat mencolok. Dengan demikian manusia itu memilki kelebihan dan kekurangan, juga manusia tidak ada yang Maha, yang Maha hanyalah milik Allah Tuhan Yang Maha Esa.

$$
\text { Begitu halnya anak-anak }
$$

berkebutuhan khusus selain mereka memiliki kekurangan juga mereka memiliki kelebihan, hanya saja manusia pada umumnya terhadap anak-anak berkebutuhan khusus hanya memandang pada kelemahannya saja (kekurangannya) seakan-akan anak berkebutuhan khusus itu merupakan beban, orang yang tidak berguna, hidupnya ketergantungan pada lingkungan, karana kebanyakan orang menganggap tidak berguna kepada anak berkebutuhan khusus. Oleh karena itu masih banyak anak berkebutuhan khusus belum mendapat kesempatan yang sama dengan anak-anak lainnya untuk mendapatkan layanan pendidikan.

Padahal berdasarkan UndangUndang 1945 pasal 31 ayat 1 dan UU No 20 Tahun 2003 tentang sisitem pendidikan Nasional dapat disimpulkan bahwa Negara memberikan jaminan sepenuhnya kepada anak berkebutuhan khusus untuk memperoleh layanan pendidikan yang bermutu dan memberikan warna lain dalam penyediaan pendidikan bagi anak berkebutuhan khusus. Pada penjelasan pasal 15 tentang pendidikan khusus disebutkan bahwa pendidikan khusus merupakan pendidikan untuk peserta didik yang berkelainan atau peserta didikyang memiliki kecerdasan luarbiasa yang diselenggarakan secara inklusif.

Pasal inilah yang memungkinkan yang memungkinkan terobosan bentuk pelayanan pendidikan bagi anak berkebuthan khusus berupa penyelenggaraan pendidikan inklusif. Pendidikan inklusif mendidik anak berkebutuhan khusus bersama-sama dengan anak lainnya untk mengoptimalkan potensi yang dimiliki, hal ini dilandasi oleh kenyataan bahwa di dalam masyarakat terdapat anak normal atau rata-rata dan anak berkebutuhan khusus yang tidak dapat dipisahkan sebagai suatukomunitas. Oleh karena itu anak berkebutuhan khusus perlu diberi kesempatan dan peluang yang sama dengan anak normal untuk mendapatkan pelayanan pendidikan di sekolah terdekat.

Pendidikan inklusif diharapkan dapat memecahkan salah satu persoalan dalam penanganan pendidikan bagi anak berkebutuhan khusus selama ini, karena awalnya anak-anak berkebutuhan khusus hanya bisa diterima di sekolah-sekolah khusus yakni SLB. Pada umumnya lokasi SLB (Sekolah Luar Biasa) di ibu kota kabupaten, padahal anak-anak berkebutuhan khusus tersebar hamper di seluruh daerah (kecamatan/desa), tidak hanya di ibu kota kabupaten. Akibatnya sebagian dari mereka, terutama dari kemampuan ekonomi orang tuanya lemah, terpaksa tidak di sekolahkan karena lokasi 
SLB jauh dari rumah, sementara kalau akan di sekolahkan di SD terdekat sekolah tersebut tidak bersedia menerima karena merasa tidak mampu melayaninya. Sebagian yang lain mungkin selama ini dapat diterima di sekolah terdekat namun karena ketiadaan guru pembimbing khusus akibat mereka beresiko tinggal kelas dan akhirnya putus sekolah. Permasalahan tadi atas dapat berakibat pada kegagalan peogram wajib belajar.

Maka dari itu pendidikan inklusif diselenggarakan dengan tujuan memberikan kesempatan yang seluasluasnya kepada semua anak termasuk anak berkebutuhan khusus mendapat pendidikan yang layak sesuai dengan kebutuhannya menciptakan system pendidikan yang menghargai keaneka ragaman, tidak diskriminatif serta ramah terhadap pembelajaran.

Oleh karena itu interpretasikan dan orientasikan lagi kepada konsep yang sebenarnya pendidikan inklusif itu, sebagai mana mengacu kepada penyelenggaraan pendidikan inklusif di Negara Amerika dan Negara Eropa, serta sebagaimana yang dinyatakan oleh Dirjen PLB (2007) bahwa sasaran pendidikan inklusif secara umum semua peserta didik yang ada di sekolah reguler, tidak hanya mereka anak berkebutuhan khusus, tetapi juga mereka yang termasuk anak normal. Secara keseluruhan harus memahami dan menerima keaneka ragaman dan perbedaan individu.

Secara khusus anak-anak berkebutuhan khusus melalui pendidikan inklisif dapat diberikan program pembelajaran yang sesuai, dengan menggunakan kurikulum regular yang berlaku di sekolah umum, namun demikian karena ragam hambatan yang dialami peserta didik berkebutuhan khusus sangat bervariasi mulai dari sifat yang ringan, sedang, sampai berat maka dalam implementasinya disesuaikan dengan kebutuhan peserta didik, seperti:

1. Peserta didik yang berkebutuhan khusus mengikuti kurikulum reguler sama dengan kawan-kawan yang lainnya di kelas yang sama program layanan khususnya lebih diarahkan kepada proses pembimbingan belajar, motivasi dan ketekunan belajar.

2. Kurikulum reguler dengan modifikasi adalah anak berkebutuhan khusus yang mengikuti pembelajarannya ada dimata pelajaran tertentu bedasarkan kurikulum reguler, sedangkan mata pelajaran yang lainnya berdasarkan PPI (Program Pembelajaran Individu)

3. Model kurikulum PPI (Program Pembelajaran Inividual) yang dikembangkan oleh tim pengembang yang melibatkan guru kelas, guru pendidikan khusus, kepala sekolah, orang tua dan tenaga ahli yang terkit, model ini diperuntukan bagi siswa yang mempunyai hambatan belajar yang tidak memungkinkan untuk mengikuti proses belajar berdasarkan kurikulum reguler. Siswa berkebutuhan khusus ini dapat dikembangkan potensi belajarnya dengan menggunakan Program Pembelajaran Individual (PPI) dalam seting kelas reguler. Sehingga mereka bisa mengikuti proses belajar sesuai dengan fase perkembangan dan kebutuhannya.

Tenaga Pendidik pada Pendidikan Inklusif meliputi guru kelas, guru mata pelajaran, (pendidikan agama, serta pendidikan jasmani dan kasehatan) dan guru pendidikan khusus (GPK). Guru kelas bertugas menciptakan iklim kelas yang kondusif sehingga anak-anak merasa nyaman belajar di kelas, menyusun dan melaksanakan asesmen pada semua anak untuk mengetahui kemampuan dan kebutuhannya. Menyusun program pembalajaran individual (PPI) bersamasama dengan guru pendidikan khusus (GPK).

Melaksanakan kegiatan belajarmengajar, mengadakan penilaian untuk semua mata pelajaran kecuali pendidikan agama dan pendidikan jasmani dan kasehatan. Memberikan program 
remedial/pengayaan bagi peserta didik yang membutuhkannya, sedangkan tugas guru pendidikan khusus adalah sebagai berikut.

1. Menyusun instrumen asesmen pendidikan bersama-sama dengan guru kelas dan guru mata pelajaran

2. Membangun sistem koordinasi antara guru, pihak sekolah dan orng tua peserta didik.

3. Melaksanakan pendampingan anak berkebutuhan khusus pada kegiatan pembelajaran bersama-sama dengan guru kelas/guru mata pelajaran.

4. Memberikan bantuan layanan khusus bagi anak-anak berkebutuhan khusus yang mengalami hambatan dalam mengikuti kegiatan pembelajaran di kelas umum, berupa remedial atau pengayaan.

5. Memberikan bimbingan secara berkesinambungan dan membuat catatan khusus kepada anak-anak berkebutuhan khusus selama mengikuti kegiatan pembelajaran yang dapat dipahami jika terjadi pergantian guru.

Penilaian hasil pembelajaran pada pendidikan inklusif disesuaikan dengan penggunaan kurikulum yang digunakannya yakni mengunakan kurikulum reguler penuh maka penilaiannya yang berlaku pada dekolah reguler, apabila menggunakan model kurikulum reguler dengan model modifikasi maka penilaiannya menggunakan system penilaian reguler yang telah dimodifikasi sekolah, disesuaikan dengan tingkat perkembangan dan kebutuhan siswa, menggunakan kurikulum PPI (Program Pembelajaran Individual) maka penilaiannya bersifat individu dan didasarkan pada kemampuan dasarnya.

\section{KESIMPULAN}

Pendidikan inklusif sebaiknya dilaksanakan sebagaimana seharusnya, seperti yang dinayatakan oleh Direktorat Pembinaan Sekolah Luar Biasa, dengan interpretasi dan orientasinya tepat sasaran sehingga anak berkebutuhan khusus mendapat kesempatan layanan pendidikan yang sama dengan anak-anak yang lainnya tampa diskriminasi yang layanan pembelajarannya disesuaikan dengan keberadaan dan kebutuhannya, sehingga wajib belajar 9 tahun dapat terlaksana dan dapat memenuhi amanat UUD 1945 khususnya pasal 31 ayat 1 setiap warganegara berhak mendapat pendidikan dan ayat 2 berbunyi setiap warganegara wajib mengikuti pendidikan dasar dan pemerintah wajib membiayainya.

Undang-Undang No 20 Tahun 2003 Sistem Pendidikan Nasional pasal 5 ayat 1 setiap warganegara mempunyai hak yang sama untuk memperoleh pendidikan yang bermutu, UU No 23 Tahun 2002 Tentang perlindungan anak pasal 51 anak yang menyandang disabilitas fisik atau mental diberi kesempatan yang sama dan aksesibilitas untuk memperoleh pendidikan biasa dan pendidikan khusus.

\section{DAFTAR PUSTAKA}

Dirjen PLB. (2007). Pedoman Umum Penyelenggaraan Pendidikan Inklusif. Jakarta: Dirjen PLB

O'Neil, J. (1994). Can inclusion work.A Conversation With James Kauffman and Mara Sapon-Shevin. Educational Leadership. 52(4) 7-11

Stainback, W. \& Sianback, S. (1990). Support Networks for Inclusive Schooling: Independent Integrated Education. Baltimore: Paul H.Brooks

Ilahi, M. T. (2013) Pendidikan Inklusif. Yogyakarta : ARR-Ruzz Media. 